\title{
CHAPTER NINE
}

\section{'This is London calling the West Indies': the BBC's Caribbean Voices}

\author{
Glyne Griffith
}

On 27 November 1953 Henry Swanzy, the producer of the BBC's literary radio programme, Caribbean Voices, wrote from his Oxford Street office in London to the programme's West Indian contact, Gladys Lindo, in Kingston, Jamaica. His letter sought advice on editorial comments which he intended to make in a future programme.

I am thinking of referring in the next summary to the death of Seepersad Naipaul, and to the illness of Sam Selvon, and the failure to send [Derek] Walcott to Europe. The last two would be critical remarks, and perhaps you think they would not be suitable in a thing like a summary. It does seem to me that the powers-that-be ought to be made aware of the value of literary work, from the prestige point of view, and the neglect of West Indian writers is really shocking ... I might also refer ... to the arrest of Martin Carter in Guyana, one poet who was never a contributor [to Caribbean Voices]. ${ }^{1}$

Neglect of the literary talent of a new generation of Caribbean writers was, in Swanzy's mind, not only an aesthetic matter: it was economic too. The following year he learned that Oxford University had received an endowment for colonial studies from the Carnegie Foundation. $\mathrm{He}$ wrote to Margery Perham of Nuffield College in an attempt to procure funding for his programme:

The reason for my writing is that I learned yesterday from Arthur Creech Jones who was doing a broadcast that the latest gift to Oxford has been $£ 30,000$ from Carnegie for Colonial Studies. He also told me that you said that the authorities did not quite know what they were going to do with it. I wonder therefore, if you would be prepared to consider doing something to help creative writers in the West Indies particularly, but to some extent in Africa as well? ${ }^{2}$

He pointed out that the BBC's allowance for Caribbean Voices of $£ 1,500$ per year was inadequate, for (he went on) he needed to support 
promising writers, such as Sam Selvon who was trying to get a London flat for himself, his wife and their child, all recently recovered from prolonged illness; Derek Walcott, who was looking to travel to England; Eric Roach and Wilson Harris, who were facing hardships in their respective home-nations of Trinidad and Guyana; and even Vidia Naipaul who was then a young student at Oxford University.

It was not usual practice for BBC producers to seek charity in this way. It illustrates not only the colonial hierarchies reproduced inside the institutions of the BBC, but also - more positively - the degree to which Swanzy appreciated the existence of an emergent cultural formation in the Caribbean which needed support from the centre. ${ }^{3}$ This was a new culture which depended, in part, on the migration from periphery to centre - discussed in other chapters in this volume. But the story does not follow any easy symmetry. What might be called a West Indian perspective also complicated Britishness and, conversely, a sense of British rectitude could complicate West Indian affiliations. Movement of personnel was only part of the issue. The story of Caribbean Voices demonstrates that conservative colonial attitudes could be as prevalent at the periphery as at the imperial centre, and conversely, that hostility toward the myopic authority of colonial culture could be active among those of privilege and influence within the imperial centre.

The programme that evolved into Caribbean Voices was initially conceived by the Jamaican journalist and poet, Una Marson. ${ }^{4}$ In March 1943 Marson had organised a feature programme for the BBC overseas service entitled Calling the West Indies. Through this medium Caribbean servicemen based in Britain during the second world war were able to maintain contact with relatives and friends back home. After a while, as a result of Una Marson's initiative, the programme began to include literary and cultural features from the Caribbean.

Marson's own reputation as a journalist had been formed in the heat of the Jamaican riots of May 1938, when she reported for the Jamaica Standard. Her editor, William Makin, prevailed upon her to travel to London in order that she could report on the Moyne Commission, which had been established by the imperial government to inquire into the causes of the Caribbean insurrections. While in London, Marson met with the 1939 winner of the Miss Jamaica competition, Winnie Casserley, who was visiting the mother country as part of her prize. When Winnie Casserley was interviewed by the BBC Marson, who had accompanied her as a journalist for the Standard, joined her. BBC staff were impressed by Marson's performance and offered her freelance work on Picture Page, where she worked closely with the producer Cecil Madden. ${ }^{5}$ As Delia Jarrett-Macauley indicates: 


\section{GLYNE GRIFFITH}

Marson kept in frequent contact with Cecil Madden, occasionally suggesting programme alterations for West Indian broadcasts ... Grateful and impressed, Madden took up a number of her suggestions, forwarding them to his colleagues. Whenever possible he aimed to increase and improve the West Indian service ... BBC broadcasts to the Caribbean region were abysmally few. A detailed BBC memorandum written in 1929 had exposed the lack of facilities in the West Indies and colonial Africa and the discrepancy between this and the service to other parts of the empire. No attempt was made to serve the West Indies except on special occasions such as test matches, and therefore no in-house expertise existed. With the outbreak of war, therefore, the quandary troubling senior staff at the Empire Division responsible for West Indian programming was twofold. One issue was the delicate handling of British policy towards colonies where nationalist activism had been in ascendancy during the late 1930s - a political challenge also for the Ministry of Information under whose general influence the BBC now operated. The second, lesser consideration was the staffing of this section, bearing in mind financial and other managerial constraints, such as supervision. ${ }^{6}$

Thus the impetus for the programme derived in part from British concerns about the escalation of nationalist sentiment in the Caribbean, particularly in the aftermath of the crisis of the 1930s. Yet with no inhouse expertise the $\mathrm{BBC}$ was obliged to call upon intellectuals from the West Indies.

As Marson's career at the BBC suggests, however, there could never be any firm distinction between the Corporation's wish for boosting the morale of the colonies for the war-effort, on the one hand, and on the other, the formulation of a wider cultural strategy which carried with it the prospect of emancipation from colonialism. As Jarrett-Macauley states:

She was invited to broadcast morale-boosting talks on West Indians and the war effort: 'The empire at war and the colonies' went out on 1 April 1940 and 'West Indians' part in war' later that month. She ended one broadcast: 'I am trying to keep the flag flying for dear old Jamaica in my own way here and I am always in a rush as I used to be over there. Special love for you, my sisters. ${ }^{7}$

Marson's pioneering work with the BBC spanned a five-year period, from April 1940 to December 1945. Her early participation in the West Indian Service had led to an invitation to contribute to the poetry magazine series, Voice, edited by George Orwell for the Indian Service. She read poetry over the airwaves alongside T. S. Eliot, William Empson and other notable literary figures. It was as a result of this experience that she devised a specifically Caribbean version of the same sort of programme. 
Caribbean Voices, twenty-five minutes long, was first broadcast on BBC's West Indian service on 11 March 1943, with June Grimble as announcer and Cameron Tudor reading a short story by R. L. C. Aarons, 'Mrs. Arroway's Joe.' The following week the late-night broadcast displayed a wider range of Caribbean authors, including Neville Guiseppe of Trinidad, John Wickham, Barbadian short-story writer and later editor of the influential literary magazine Bim, and Ruth Horner, a Jamaican poet. The Jamaican literary journals, Edna Manley's Focus and the Poetry League of Jamaica's yearbook for 1940 were used as sources. Constance Hollar, the Jamaican poet and an acquaintance of Una's, who had died earlier that year, was the subject of the third programme. ${ }^{8}$

Marson had to operate in difficult conditions, not only confronting senior figures in the $\mathrm{BBC}$ whose commitments to the Caribbean were, to say the least, unreliable, but in addition a range of sceptical opinion in the West Indies itself. The very centrality of Caribbean Voices - the fact that it was the only such programme broadcast from London - inevitably meant it became a hostage to fortune, each enthusiastic listener convinced of its partiality. It was faulted for its narrowness. For example, one Mr Minshall, the government's Information Officer for Trinidad and Tobago, complained to Madden that it was unpopular in Trinidad because (he insisted) there was too much attention on Jamaica. West Indian critics blamed Marson for what they saw as the many shortcomings of the programme, which they always seemed ready to adumbrate. ${ }^{9}$ Despite these challenges Marson pressed on, sure in her own convictions, and in this she was ardently supported by John Grenfell-Williams, who as Director of the African Service also had responsibility for broadcasting to the English-speaking Caribbean.

The personal costs were high. Marson herself experienced a sense of isolation within the $\mathrm{BBC}$, which was aggravated by an increasing feeling of distance from the Caribbean, whose world she was responsible for representing. She knew too that she needed to widen her knowledge of the Caribbean beyond the culture of her own native Jamaica. After the war had ended she obtained permission from the $\mathrm{BBC}$ to make an extended five-month trip to the Caribbean.

I felt that somehow I must leave London and come to the West Indies. I wanted to get away from the cold and the atmosphere of war, but more than anything else I wanted to come to the West Indies to meet as many people as possible to whom I had been speaking for nearly five years. I asked for permission to come, feeling very definitely that I could not go on broadcasting to you without learning about life in other islands of the West Indies I had not visited before. ${ }^{10}$

Soon after her return to London, however, she found herself overwhelmed by the pressure of her travels and debilitated by her continuing 


\section{GLYNE GRIFFITH}

sense of isolation at the BBC. She became increasingly despondent succumbing to the clinical depression which had haunted her for years. After a brief period in a nursing home in the English countryside, she returned home with her friend, the Jamaican poet Clare McFarlane, in April 1946. This departure brought an end to her official relationship with the $\mathrm{BBC}$, and with the programme that she had been instrumental in establishing.

When it became clear that Marson could no longer carry on, John Grenfell-Williams invited the English writer, and close friend of Marson's, Mary Treadgold to organise the Caribbean Voices broadcasts until a more permanent appointment could be found. After three months Henry Swanzy, who was already employed as a producer in the Overseas Service, was asked to serve as producer and editor of Caribbean Voices.

Alongside the new appointment Grenfell-Williams understood that, in Marson's absence, the BBC needed someone 'on the ground', based in the Caribbean. He arranged that a regional office be set up in Kingston, and appointed a local man and friend of Marson's, Cedric Lindo, to act as Caribbean representative. In an unexpected development, however, Lindo didn't want to be seen to compromise his public standing, so proposed that his wife, Gladys, should take his place. (Cedric Lindo worked for the Jamaica Fruit and Shipping Company: it is revealing that he should think that working for the $\mathrm{BBC}$ as a literary agent might be considered a conflict of interests. $)^{11}$

Swanzy, clearly, needed this regional support. He was an Irishman, trained as a historian, and - alongside his professional work at the BBC - an aspiring poet in his own right. Much later in life he reflected on the commitments which animated him:

An odd passage through life which might explain something to the alert. The key, I think, has been my sympathy with the different peoples brought into contact by an imperial structure, perhaps too much linked by politics and economics, and not enough by art and culture. ${ }^{12}$

Grenfell-Williams had first become aware of Swanzy's literary interests when in 1941 the latter had submitted a long poem on the Battle of Britain to the BBC. The poem, in fact, received only rather measured praise from the influential writer, Cecil Day Lewis. In Swanzy's later recollections, this rebuff was connected to his subsequent championing of Caribbean writers.

Cecil Day Lewis said things about the poem which were justified, I think, but still he might have been a little less lukewarm. Thereafter, I never had sufficient confidence as I didn't get much encouragement, really, and I thought, perhaps out of a sort of empathy, that it would be nice to assist 
some of these writers from the West Indies if I could, because they didn't get much help either, really. ${ }^{13}$

Swanzy came to Caribbean Voices, therefore, with literary interests, with experience in broadcasting, and with some empathy for aspiring writers who, like himself, had lacked encouragement and guidance. What, though, of the Caribbean? When late in his life I asked him about this, he answered in the following way:

I mean, one had the idea of Glory Dead which one had read, and one also had the sort of 'left-wing' view of encouraging people who had had a raw deal, really ... And my problem of course is that I come from Ireland, you see. I'm Irish, and although I left Ireland when I was five and never went back, or seldom did, one did have the feeling that what one wrote and was interested in was not the kind of thing that somebody like a Philip Larkin or a Gavin Ewart would write, really. ${ }^{14}$

This answer fuses together a number of issues. It conveys the mild though nonetheless significant democratic or egalitarian spirit common to many creative artists in Britain during the mid 1940s, when Swanzy first took over Caribbean Voices. It expresses a continuing allegiance to Ireland which set him apart from the conventions of the English literary establishment - a commitment which remained with him, judging by the names he cites, who were poets famous at the time he was speaking (in 1992) rather than in the time of Caribbean Voices. And it alludes to a book, Glory Dead, written by Arthur Calder-Marshall. It was through this book that Swanzy's imagination had been touched by the Caribbean.

Given the salience of this book for Swanzy, and given too the fact that he persuaded Calder-Marshall to become involved in Caribbean Voices, it is worth indicating something of the context. In 1938, the year following the height of the social unrest in Trinidad, CalderMarshall spent three months in Trinidad and Tobago. His background was that of a conventionally English man of letters - private school, Oxford, and a string of novels by the time he was in his early thirties, when he embarked on his trip to the Caribbean. Glory Dead recounts this experience. It is, partially, a predictable piece of travel-writing, bringing together a range of vignettes of the social life of the islands. But the radical tempo of literary life in Britain in these years, combined with the political volatility of the Caribbean, gave the book a sharper subversive edge. Calder-Marshall wanted his account to confront the problem of 'white domination', and one of its themes is the 'shame' he experienced as a 'white man'. ${ }^{15} \mathrm{He}$ became involved, initially, with the cultural circles which existed on the edge of the labour movement, lecturing on aesthetic matters at L'Ouverture Club, speaking again to the 
Oilfield Workers' Union, and eventually attempting to put on a production of that classic play of the anglophone Popular Front, Waiting for Lefty. (On his death the Daily Telegraph quaintly observed that in the 1930s he had 'experimented' with marxism. $)^{16}$ Gradually, it seems, he was pulled into social and political agitation. He attended various demonstrations (including one which was addressed by Clement Payne, who had recently become the hero of the disaffected masses of Barbados), spoke at some, and before long became the object of police attention. Glory Dead represents perhaps the only sympathetic recounting of the labour unrest in the Enlish-speaking Caribbean, written from a colonial perspective, though it is now almost completely forgotten. His conclusions were forthright:

The struggle of the coloured worker will not be peaceful, because force will be used to suppress each effort towards greater responsibility, in the same way that force was used in Trinidad and Barbados in 1937 and in Jamaica and British Guiana in 1938. Commissions will be appointed as they have been in the past. They will make recommendations, most of which will be ignored. But each time certain advances will be made ... A new spirit has arisen among the workers. They have tasted freedom; they begin to know their power. And they intend to use that power, not as whites fear and perhaps like to think, for the stupid display of violence, but for the attainment of better education, better conditions of work and a higher standard of life. ${ }^{17}$

There are in the book, it is true, more conventional accounts of the lives of the subordinated in the Caribbean, which repeat the common prejudices of colonial mentalities of the period. But these are offset by an appreciation of the complexity of social interaction in everyday situations, and by an astute sense of the power of collective memory. Here, for example, Calder-Marshall tries to enter the imagination of an 'ordinary' Trinidadian working woman, in order to reveal the psychological workings of racial subordination:

Mrs. Tournevant's great-grandmother was freed from slavery when she bore her master's bastard. As she talks to Mrs. Wilson, she is torn in two directions. Being seen talking to a white woman raises her prestige among neighbours and that gives her pleasure. But she knows that behind Mrs. Wilson's affability is contempt and maybe hatred. The pretence of equality is a mask for white superiority: it is like a millionaire wearing dungarees. She is being patronised and she is submitting to being patronised to gain caste with neighbours. So Mrs. Tournevant, laughing and smiling, hates Mrs. Wilson from West Kensington, and hates herself for talking to her. ${ }^{18}$

Such reflections on the masquerades of white supremacy were not usual in colonial discussion of the Caribbean in the 1930s. 
'THIS IS LONDON CALLING THE WEST INDIES'

Glory Dead also demonstrated a knowledge of Caribbean literature. As much as in the sphere of politics, Calder-Marshall had definite - and judged again by the colonial conventions of the time - unorthodox views on aesthetics. Here he comments on a lecture he delivered on art and society at the L'Ouverture Hall in Port of Spain:

I tried to describe the way literature springs from the relation of the author, with his gifts, to the society of his time, and the variations thus entailed between literatures of different countries and ages. I pointed to Alfred Mendes as a Trinidadian novelist who represented native qualities of the island. I deplored the local verse as derivative from the Victorian and Edwardian traditions of English literature and having no relation to the life of the island ... I tried to explain ... [t]hat universality is only achieved by particular definition of character. I tried to make plain that a great work of art could be enjoyed by a wide audience, but that it would only be a great work of art if it had its roots in the life and thought of a particular time and place. ${ }^{19}$

This championing of a popular, locally rooted aesthetic, shaped by the social relations of its own colonised locations, marked the cultural dimensions of Calder-Marshall's commitments to a broader progressive politics. It also anticipated the intellectual affiliations of Caribbean Voices.

It's not certain how Swanzy came across Glory Dead, nor if this represented his sole means of access to the literary culture of the Caribbean. It is clear, though, that some fifty years after the event he could talk of the book as if it were a common cultural landmark for those who were serious in knowing about the Caribbean. CalderMarshall and Swanzy shared the hope of bettering the lives of those 'who had had a raw deal', and shared too a scepticism about the spurious claims of a - metropolitan-driven - universal aesthetic. CalderMarshall argued in terms of the need for a literature rooted in 'the life and thought of a particular time and place', while Swanzy made the same point by invoking the need for 'local colour'. In 1946, during his first year as editor of the programme, Swanzy explained his reasons for rejecting various manuscripts which had been forwarded to him:

I am gradually working my way into the stockpile of Caribbean Voices, and now return various manuscripts which I do not think we should like to use. As you will see, they include several classes: patriotic poems, sweetly pretty poems ... and finally, the occasional exiles writing about conditions which have nothing to do with the Caribbean. On the whole, I think they all have something in common, and that is a complete absence of local colour. That seems to me to be the greatest crime in this series, unless of course the writer is a genius with a universal message. ${ }^{20}$ 
In a strange paradox, this determination to support what Swanzy called the 'local' undermined what many aspiring - 'local' - writers in the Caribbean considered to be a proper mode of writing. As the piles of rejected manuscripts attest, many of those West Indians who submitted work to Swanzy believed that art should reproduce the literary conventions of the metropolis - or at least, those with which they had been able to become acquainted. Swanzy's conception of the local, however, was set dead against the 'patriotic' and 'sweetly pretty'.

If this strategy discriminated against tradition it did so in favour of encouraging a wider plurality of authorship. As the Jamaican academic and poet, John Figueroa, has observed:

$[\mathrm{O}]$ ne of the great contributions of Caribbean Voices was that it offered an outlet to all and sundry, as any full list of its contributors shows. And in doing this it executed an odd twist and inversion of what would then have been considered the proper metropole/periphery relationship. ${ }^{21}$

Critical in this respect was the question of language. Swanzy's espousal of regional forms embraced a vernacular manner of writing that transgressed the cultural norms which, in other arenas, were propagated fiercely by the BBC. Figueroa, who as a reader on the programme was caught in the crossfire of these controversies, goes on to say:

One is not dealing just with a general tendency of critics, but with special complicated Caribbean 'colonial' attitudes. Nothing better illustrates this than the fact that many people in the Caribbean felt that poetry on the BBC, even Caribbean poetry, should be read by English voices ... Often critics appear to be criticizing individual readers, almost to be carrying out a vendetta, but when one looks more carefully, and observes who are strongly praised as readers, one cannot help noticing that they are either English or have very 'Oxford English' voices ... The very existence of Caribbean Voices, and particularly its mode of operation, raised the whole question of the meaning and actuality of the metropole/periphery relationship: the relationship between London and the Caribbean. ${ }^{22}$

Swanzy was quick to employ readers on the programme such as Sam Selvon from Trinidad, Pauline Henriques from Jamaica, George Lamming from Barbados, and other London-based, Caribbean writers and artists. Indeed, his critical sense of the uniqueness of an emergent Caribbean literature necessarily turned on the question of language, and more especially on the particularities of idiomatic expression. Interviewed in later years he put it like this: 'It is certainly true that the dialect, the accent and the turn-of-phrase, the spoken language was extremely rich; I always remembered phrases such as, "Their eyes made four"' ${ }^{23}$ The more West Indians came to London, the more he was able to employ West Indians as readers. In retrospect, this may 
seem an obvious thing to have happened, an elementary requirement that the West Indian imagination be represented - spoken - by West Indians. But this is to underestimate the reflexes of social authority underwriting language itself, such that the attainment of culture excluded those who (in the colonial situation) could not, or would not, master the correct forms. Many listeners assumed that, on this question above all, the BBC would hold the line. When, under Swanzy's direction, Caribbean Voices made evident its conviction that commitment to the local meant also commitment to local vernacular idioms, a certain disarray could be discerned in the ranks of the programme's West Indian audience. In response to one broadcast, for example, Gladys Lindo complained that:

Incidentally, there were some very caustic remarks from my friends on the programme of the 2 nd November. There was quite a large group listening - fourteen in all - and the opinion of the majority was that it was not only poor, but very poor.

I was unable to identify the story, as I missed the name and did not recognise it as one passed through this office... The reader also was not good. I think it was Mr. [Gordon] Bell of Barbados. I appreciate that it is better to have West Indians reading in the programme, but suggest that if it is not possible to get a good West Indian reader, a good English one would be preferable. ${ }^{24}$

The complaints from Lindo's office regarding Barbadian reader, Gordon Bell, as well as the Jamaican reader, John Figueroa, were prominent themes of several of Lindo's letters to Swanzy during the early period of his direction. By June 1948 it was clear that Swanzy had had enough.

Dear Mrs. Lindo,

Far from 'sitting in a corner and weeping', he [Michael G. Smith, whose poetry John Figueroa had read on a previous broadcast] said that Figueroa read better than he could himself, and although he thought he was a little bit histrionic, he thought it was a very good performance. In this, I must say that we all agree over here, including Mr. Grenfell-Williams ... don't you think that the campaign of criticism in Jamaica may not be unconnected with the founding of a local poetry programme by the local poetry 'ring'? ... The long and the short of it is that we shall continue to regard Figueroa as our main poetic exponent, but we shall try to get more variation in readers, perhaps from some of the West Indian actors and others who are living in London. I still think it would be a pity if we went back to the BBC Repertory Company. ${ }^{25}$

Swanzy's determination to privilege the local also had unexpected consequences. He soon received many more submissions in the local vernacular. This brought with it the discovery, though, that there were many 'locals'. Listeners in each island believed that the particular 


\section{GLYNE GRIFFITH}

rhythms of their speech were necessary to communicate the intricacies of their own particular forms of writing. To have a Jamaican read a Bajan poem could seem like another sort of external authority imposing itself, even if it were in the name of a larger nationalism. In a radio programme dedicated to the integrity of the spoken word, controversies such as these were both inevitable and decisive.

It's difficult to judge the effect that the medium of radio - pre-eminently through Caribbean Voices - had on encouraging an entire generation of writers to think in new ways about representing the tone of the spoken voice on the page. There can be no doubt, however, of the more general significance of Caribbean Voices in creating a new West Indian literature. George Lamming recalled it in these terms:

Our sole fortune now was that it was Henry Swanzy who produced Caribbean Voices. At one time or another, in one way or another, all West Indian novelists have benefited from his work and his generosity of feeling. For Swanzy was very down to earth. If you looked a little thin in the face, he would assume that there might have been a minor famine on, and without in any way offending your pride, he would make some arrangement for you to earn. Since he would not promise to 'use' anything you had written, he would arrange for you to earn by employing you to read. No comprehensive account of writing in the British Caribbean during the last decade [the 1950s] could be written without considering his whole achievement and his role in the emergence of the West Indian novel. ${ }^{26}$

But at the same time, the flux of new readers and writers passing through Swanzy's office ensured that different aspects of Caribbean culture came to life, new viewpoints were opened and, inevitably, that the authority of the likes of Calder-Marshall began to diminish. One little bit of the BBC not only serviced the Caribbean: in so doing it quietly became creolised.

Notwithstanding competing claims on local idioms, Swanzy's insistence on submissions that spoke in a voice that was peculiarly West Indian led many writers from the region to cast what Kamau Brathwaite would later call 'nation-language'. Respecting local forms while attempting to imagine into existence a larger Caribbean reality was not easily achieved - though Caribbean Voices clearly contributed to the possibility of imagining a federation of the English-speaking West Indies as a unified cultural region.

Laurence Breiner believes that the privileging of the spoken voice, which radio demanded, proved vital in this respect.

It was a great piece of luck for the development of West Indian poetry that the cachet of metropolitan approval came first of all not in the form of publication by a British anthology or magazine (venues which would con- 
sciously or not have tended to encourage more exotic subject matter and less exotic language), but in the form of a radio program that made poets think about how their work would sound to a diverse West Indian audience listening at home. ${ }^{27}$

John Figueroa makes a similar point, though emphasising the specifics of wireless technologies:

The other great source of influence which Caribbean Voices possessed is very easy to overlook or underestimate in this age of TV and satellites: it was a radio programme, a short-wave radio programme. That would have been important anywhere, but it was pre-eminent in the Caribbean, where 1200 miles of sea separated Trinidad and Jamaica, and where communication was by infrequent ocean liners from North to East and South, or by regular schooner in the South. Short-wave radio really eradicated time and space. And Caribbean Voices brought together those who were interested from St. Lucia and Tortola and Guiana and Trinidad and Barbados and Jamaica in a way that nothing else, except cricket broadcasting, ever has. Furthermore, in a society not too well known for reading, the spoken word, by way of radio, even when it was producing literature, had an impact that books would have lacked, except among the very few. ${ }^{28}$

For a critical period Caribbean Voices, organised from the metropole, became the medium for a new Caribbean literature. Swanzy, and the programme he nurtured, allowed many West Indians both in Britain and in the Caribbean, to become intellectuals and artists. And in so doing, they created the means for imagining a new homecoming, not only for themselves, but for the multitudes they represented.

\section{Notes}

1 Henry Swanzy, letter to Gladys Lindo, 27 November 1953, Henry Swanzy Archive, Birmingham University Library, UK.

2 Henry Swanzy, letter to Margery Perham, 14 July 1954, Swanzy Archive.

3 For a slightly later reflection on the colonial relations inside the BBC, see George Lamming's angry comments in The Pleasures of Exile (London: Allison and Busby, 1984; first published 1960), p. 51.

4 Rhonda Cobham, 'The Caribbean Voices programme and the development of West Indian short fiction, 1945-1958', in Peter Stummer (ed.), The Story Must Be Told: short narrative prose in the new English literatures (Bayreuth: Konigshanson and Newmann, 1986), pp. 146-60.

5 Delia Jarrett-Macauley, The Life of Una Marson, 1905-65 (Manchester: Manchester University Press, 1998), p. 144. Madden went on to become a pioneer of TV light entertainment, renowned for his discoveries of Petula Clark, the Beverley Sisters and Jimmy Edwards.

6 Jarrett-Macauley, Marson, p. 146.

7 Jarrett-Macauley, Marson, p. 147.

8 Jarrett-Macauley, Marson, p. 158.

9 Jarrett-Macauley, Marson, p. 152.

10 Jarrett-Macauley, Marson, p. 167. 


\section{GLYNE GRIFFITH}

11 Wycliffe Bennett (former secretary of the Jamaica Poetry League), personal interview, 30 March 2001.

12 Henry Swanzy, letter to the author, 2 November 1993.

13 Henry Swanzy, personal interview, 24 October 1992.

14 Swanzy, interview, 24 October 1992.

15 Arthur Calder-Marshall, Glory Dead (London: Michael Joseph, 1939), pp. 12 and 100. The title comes from an old local song. It re-emerges later in V. S. Naipaul: 'The history I carried with me, together with the self-awareness that had come with my education and ambition, had sent me into the world with a sense of glory dead; and in England had given me the rawest stranger's nerves', The Enigma of Arrival: a novel (Harmondsworth: Penguin, 1987), p. 52.

16 Obituary of Arthur Calder-Marshall, Daily Telegraph, 20 April 1992. For an interesting (and positive) review of Glory Dead, see New Leader, 19 May 1938. George Lamming can also be found recommending Glory Dead in 'Music of language. An interview with Erika Waters', The Caribbean Writer, 13 (1999). He tells of CalderMarshall's role in helping get In The Castle of My Skin published in Ian Munro and Reinhard Sander (eds), Kas Kas. Interviews with three Caribbean writers in Texas. George Lamming, C. L. R. James and Wilson Harris (Austin, Texas: African and Afro-American Research Institute, University of Texas at Austin, 1972).

17 Calder-Marshall, Glory Dead, p. 239.

18 Calder-Marshall, Glory Dead, p. 43.

19 Calder-Marshall, Glory Dead, pp. 148-9.

20 Henry Swanzy, letter to Gladys Lindo, 13 August 1946, Swanzy Archive.

21 John Figueroa, 'The flaming faith of these first years: Caribbean Voices', in Maggie Butcher (ed.), Tibisiri: Caribbean writers and critics (Aarhus: Dangaroo Press, 1989), p. 72.

22 Figueroa, 'Flaming faith', pp. 61-3.

23 Henry Swanzy, personal interview, 22 October 1992.

24 Gladys Lindo, letter to Henry Swanzy, 10 November 1947, Swanzy Archive.

25 Henry Swanzy, letter to Gladys Lindo, 23 June 1948, Swanzy Archive.

26 Lamming, Pleasures of Exile, p. 67.

27 Laurence Breiner, Black Yeats: Eric Roach and the politics of poetry (unpublished ms, Boston University, 2000), p. 7.

28 Figueroa, 'Flaming faith', pp. 72-3. Figueroa has also emphasised the importance of Caribbean Voices in bringing the larger world into the enclosed culture of the Caribbean, which he discusses in his contribution to the BBC Radio 4 documentary, What does Mr Swanzy want? (first transmitted 27 November 1998; presented by Philip Nanton). Although no recordings remain, this commemoration provides a rich portrayal of the defining themes, and shows too the degree to which Swanzy's paradoxical espousal of the local - from his BBC redoubt in London - was the cause of deep resentments. 